体育学研究, 34：305-316, 1990 .

\title{
コーチの社会的勢力の基盤と機能
}

$$
\begin{aligned}
& \text { 森恭1) 伊藤豊 彦2) } \\
& \text { 豊田一成3) 遠藤俊 郎4) }
\end{aligned}
$$

\section{The bases and functions of coaches' social power}

\author{
Yasushi Mori ${ }^{1}$, Toyohiko Ito ${ }^{2}$, Kazushige Toyoda ${ }^{3}$ and Toshiro Endo ${ }^{4}$
}

\begin{abstract}
The purpose of this study was to make clear the bases and functions of coaches' social power. Three hunderd and eighty-nine players, belonging in highschool sport clubs, were administered two questionaires; one was to measure the bases of the power their coaches had, the other was to measure players' estimation of influences from coaches and their adaptability to sport activities in the clubs.

From the result of factor analysis, six bases of the power were extracted as the factors; expertise-referability, apprehension to punishment, expectation of benefit, enthusiasm of coaches, legitimacy, and affiliation to and acceptance from coaches. Then, the power of coaches were differentiated into six types in terms of the bases.

The functions of each type of power were examined by means of multiple regression analysis. It was found that coaches' personal power which included expert-reference, benefit, enthusiasm and affiliation-acceptance power had mainly contributed to coaches' influence. Especially, benefit and enthusiasm power had been playing crucial roles in coaching.

On the other hand, punishment and legitimate power, so-called position power, were found not to have significant positive effects. It was speculated that influences based on punishment power could not be accepted privately, and would have negative effects on players' adaptation to activities, and that legitimate power was in existence on personal power.
\end{abstract}

(Japan J. Phys. Educ., 34: 305-316, March, 1990.)

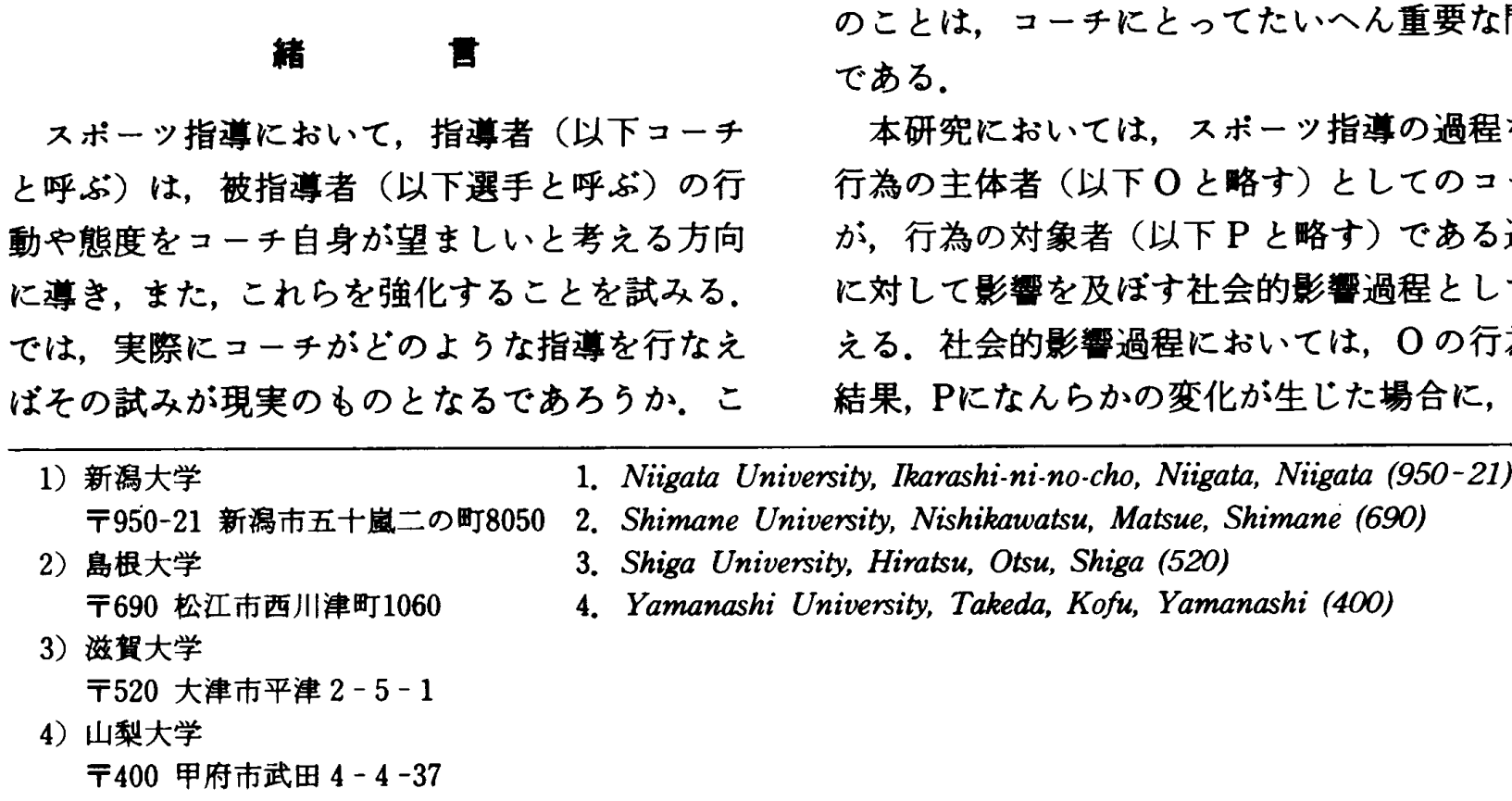

\section{緒}

スポーツ指導において，指学者（以下コーチ と呼ぶ）は，被指導者（以下選手と呼ぶ）の行 動や態度をコーチ自身が望ましいと考える方向 に導き，また，これらを強化することを試みる。 では，実際にコーチがどのような指導を行なえ 
Pに対して影睓を及ぼしたとされる。そして，O がPに対して影暗を及ぼすことができるよう な可能性を持つならば，OはPに対して社会的 势力（social power）あるいは，単に勢力を保 持するとされる5).

勏力に関しては様々な定義がなされている が4),6),11),18),22),24),30)，「O が P に影留を与え得る潜 在的な能力の最大值」年とい5定義が最も一般

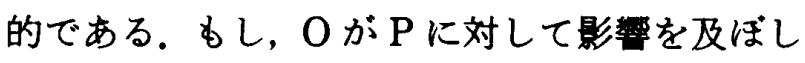
たのであれば，それは $\mathrm{O} か ゙ \mathrm{P} に$ 対して势力を保 持しているからであると解釈できる。しかし， $\mathrm{O}$ が $\mathrm{P}$ に対して势力を保持していてす，Oがこ れを行使しないか, あるいは $\mathrm{P} か ゙ \mathrm{O}$ の势力に気 つかない場合には，Oは Pに影敏を及ばすこと はできない。このような意味において，慜力は 潜在的な影䱥であると考えられ，逆に，影留は 活動状態にある勢力と考えられる。

スポーツ指導の過程をこのような社会的影鉏 過程として捉えたならば,コーチの指導の効果 は,コーチの行なら指普の内容や方法などの実 質的な影響の試みだけでなく、コーチが選手に 対して保持している勢力にも依拠していると考 えられる，そこで本研究は，選手に対してコー チの保持している勢力がどのような基盤に基づ いているかを明らかにし，それぞれの基盤に基 ついた各勢力がどのような機能を果しているか を検討することを目的として行なわれた。この ような試みは、コーチが奻果的な指導を行なっ たり，自身の指導を診断するための基礎的な知 識，あるいはコ一千教育のための基礎資料を提 供するものと考える。

ところで，勢力の基盤にはいくつかの質的に 異なるタイプが考えられる，たとえば, French and Raven ${ }^{12)}$ は，対人間の一般的な势力をその 基盤から報酬繁力, 強制势力, 正当势力, 参照 势力, 専門勢力の 5 つのタイプに分類している。 報酬慜力は， $\mathrm{O}$ は報酬をもたらすことができる， と $\mathrm{P}$ が認知することに基づき，強制勢力は， $\mathrm{O}$ は界を加えることができる，と P が認知するこ とに基づく．正当勢力は， $\mathrm{O} か ゙$ 行動を規制する ことは正当なことである，という $\mathrm{P}$ の認識を基
盤としている，参照勢力は， Pの $\mathrm{O}$ との同一視 に基づき，そして，専門勢力は， $\mathrm{O} か ゙$ 高度な知 識を持っている, と $\mathrm{P}$ が認知することに基つくく 势力である。この分類がどのようにしてなされ たか明らかにされてはいないものの，多くの研 究がこの分類に依拠しており ${ }^{27)}$ この分類を, 勢 力を考学る際の出発点と考えることができよ $5^{17)}$.

また，スポーツ指導の場面と同様に指導一被 指導を軸とする，教育場面での教師の勢力に関 する研究も行なわれている，たとえば，田崎 ${ }^{35}$ は，児童・生徒に対する教師の势力の基盤を， 児童・生徒の認知に基ついて分析し，7つの勢 力基盤を因子分析によって因子として抽出して いる. 7 つの慜力基盤は, 教師との心理的な近 さや教師に受容されているといら認識（親近・ 受容)，教師の外見の良さ(外見性)，教師に従 らのは当然であるといら内在化された規範（正 当性), 教師の明るさ (明朗性の魅力), 教師か らの罚や教師への畏怖(谡)，教師の指導の巧さ や豊富な経検(熟練性)，そして，教師への児童・ 生徒の同一化の意図（同一化）である。

また，浜名ら ${ }^{14)}$ は，教師の持つ勢力の基盤に関 する，児童の側の認知と教師の側の認知を比較 し，人間的配虑，外面性，罚が児童に認知され ている勢力の基盤であるとしている。浜名らは, 人間的配虑を田崎 ${ }^{35)}$ 同一化之同様のむのと し，さらに親近・受容および明朗性の魅力包 摂するるのと捉え，外面性および界は田崎の研 究における勢力の基盤のそれぞれと対応すると している.

このように田崎および兵名らの研究が教師一 般の勢力を取り上げたのに対して, 平川151は, 対 象を体育教師に限定して, 势力の基盤を分析し た。この研究では，学校期別に因子分析が行な われ，体育教師の慜力の基盤が検討されている。 各段階を通じて勢力の基盤とされたものは，人 間性, 熟練性, 外見性, 罚・威王性である。こ の他に，小学校期では，同一化が外見性と $1 つ$ の因子をなし，さらに正当性が見出された。中 学校期では, 専門性と明朗性が見出されている. 
そして高校期においては，正当性，専門性，一 体性が見出されている。これらの勢力基盤は, 田崎および浜名らの研究における勢力基盤にほ ぼ対応することから，体育教師の特異性は見ら れなかったといえる。これに対して，学校期の 間の比較から，中学校，高校と進むにつれて教 師としての技量が重要な愬力の基盤として認識 される傾向が強くなり，逆に受容性の重要度が 小さくなっていくことを指摘している。

これらの研究で見出された，教育場面におけ る教師の勢力と基盤と, French and Raven ${ }^{12)}$ に おける一般的な慜力の基盤との比較から，教師 と生徒の間に特有な慜力の基盤として，心理的 な近さ(親近性)，受け入れてすらえるといら認 知(受容性)，外見の良さやかっこょさ(外見性)， 明るさ（明朗性）が挙げられている。これらの 基盤とは対照的に, French and Raven が提唱 した報酬慜力は，教師の勢力を分析した研究で は一貫して見出されていない。この点について は特に触れられていないが，教育場面の特徵と なんらかの関わりがあると考えられる。

以上のよ5に，Pに対する $\mathrm{O}$ の勢力は，その 基盤によっていくつかのタイプに分類され，ま た，Oと P が置かれている状況や場面によっ て，基盤が異なることが予想される，従って， 本研究では，まず，スポーツ指学場面における コーチの慜力の基盤を他の場面における研究と 比較し, 検討する.

一方，妿力の機能に闺しては，一般的な対人 関係場面におけるはとんどの研究が，前述した French and Raven ${ }^{12)}$ の分類に基ついて行なわ れ，概して，専門勢力および参照奻力に基づく 影苼が有奻であるとされている271,31),331,399.

また，教師の勢力の機能については，田崎 ${ }^{36)}$ は，小学校教師のリーダーシップ行動類型と勢 力基盤との関係を児童の認知に基ついて分析 し，正当性に基ついた繁力が，教師の勢力の中 で，最も効果の大きい乵力であることを指摘し ている.リーダーシップ行動類型と势力の基盤 との関係については，PM 型リーダーに対して 正当性, 親近性, 熟練性, 参照性などの得点が
高く, $\mathrm{P}$ 型リーダーに対して罚が高く，他の基盤 の得点が低かった。この結果から，教師の PM 型リーダーシップは, 正当性, 親近性, 鶁練性, 参照性の慜力基盤によって支えられ， $\mathrm{P}$ 型リー ダーシッブは，埆に基ついていると考えられた。 尚ここでは， $\mathrm{M}$ 型および $\mathrm{pm}$ 型は，繁力基盤と 明確な関連を持たなかった。

田崎 ${ }^{371}$ は，教師の势力基监と児童のスクー ル・モラール（学習動機, チーム・ワーク，目 標達成努力など）との成連を研究している。こ の結果，教師の指示に従 5理由として，正当性 と親近・受容の基盤に高い得点を付与している 児童のスクール・モラールが高く，反対に，数 師の熟力の背景に罚を認知する児童のスクー ル・モラールは低いものであった。ささらに，田 崎 ${ }^{36)}$ と同様に, 正当性に基ついた朔力が，最方効 果の大きい乵力であることが示唆されている。 他の場面における研究においては，正当性を基 盤にした繁力は効果が小さいことが指摘されて おり 27),31),33)，ここでの結果は教師の势力の場合 に限定されると考えられている14),36),37).

このよらに，朔力の基盤のみならず，勄力の 効果に関しても，O と P の関与している場面に よって異なった特質が存在することが予想され る.このため, 本研究では, スポーツ指尊の場 面において、コーチの勢力のそれぞれのタイブ が，どのよ5な機能を果しているかについても 検討を加える。そこで，まず，コーチからの影 響に闺する選手の評定（以下被影留感と呼ぶ） およびューチに対する総体的な評価としての满 足度を取り上げ，愬力基盤に対する認知との成 連を検討する。さらに，Oの势力が $\mathrm{P}$ の適応を

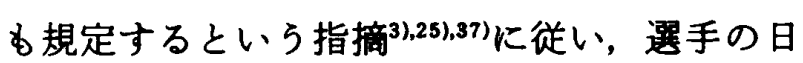
常のスポーツ活動への適応の指標として, 所属 運動部への関心, 練習への意欲, チームメイト

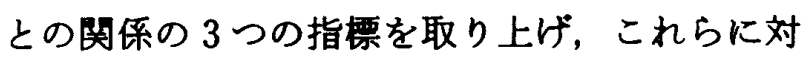
する各タイプの知力の効果についてす分析を試 みる。

\section{方法}

调查期间：昭和 62 年 12 月から昭和 63 年 1 月。 
表 1. 基盤質問紙の項目と因子分析の結果（ $\mathrm{N}=389 ）$

\begin{tabular}{|c|c|c|c|c|c|c|c|c|}
\hline 項目（番号・内容） & F1 & F2 & F3 & F4 & F5 & F6 & F7 & 共通性 \\
\hline 17 技術的に草敬しているから & 825 & -031 & 166 & 152 & 085 & 050 & -117 & 755 \\
\hline 18 監督はよいお手本だから & 795 & -039 & 215 & 190 & 17 & 165 & -090 & 783 \\
\hline 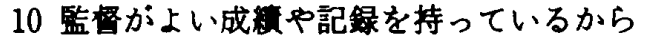 & 760 & 105 & 045 & 071 & 072 & 070 & 071 & 610 \\
\hline 33 自分より释検が㖹富だから & 725 & 114 & 217 & 187 & 042 & -057 & 011 & 626 \\
\hline 8 監督がこの竸技をよく知っているから & 722 & 073 & 227 & 170 & -033 & -063 & -082 & 619 \\
\hline 6 監督の上らになりたいから & 714 & -029 & 144 & 109 & 092 & 349 & -097 & 682 \\
\hline 29 有名な監督だから & 706 & 227 & 063 & 110 & 163 & 137 & 053 & 615 \\
\hline 13 監督が良い選手を育てたことか & 701 & 196 & 116 & 106 & 153 & 191 & 082 & 620 \\
\hline 5 自分より技術が上手たかから & 686 & 081 & 222 & 070 & 145 & -056 & -079 & 561 \\
\hline 28 監督の技術を盗みたいから & 663 & -040 & 232 & 169 & 146 & 199 & -048 & 587 \\
\hline 11 監督を信頼しているから & 573 & -172 & 377 & 305 & -041 & 294 & -230 & 734 \\
\hline 25 人間的に尊敬しているから & 560 & -082 & 265 & 344 & 116 & 401 & -119 & 698 \\
\hline 31 いろいろな技術を教えてもらえ & 552 & -027 & 527 & 295 & -115 & -070 & -147 & 709 \\
\hline 7 監督に叱られるから & 100 & 784 & 066 & 36 & 104 & 019 & -293 & 727 \\
\hline 20 監督がこわいから & 23 & 783 & 042 & -077 & 0 & 8 & -051 & 89 \\
\hline 26 反抗する勇気がないから & 072 & 720 & -044 & 007 & 051 & -110 & 017 & 41 \\
\hline 3 第がこわいから & -118 & 716 & -072 & -082 & -137 & 072 & -287 & 45 \\
\hline 35 後々やかましいから & -113 & 606 & 012 & -213 & 1 & -003 & 452 & 48 \\
\hline 23 しかたがないから & -1 & 561 & -156 & -0 & 1 & -136 & 43 & 06 \\
\hline 30 他の人がそうするから & -048 & 561 & -111 & 038 & 231 & -036 & $30^{\circ}$ & 479 \\
\hline 21 指示に従 5 & ) & 045 & 0 & 042 & 151 & 036 & 03 & 452 \\
\hline 39 自分の悪い所を直しても & 3 & -129 & & & 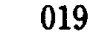 & 9 & -21 & 04 \\
\hline 1 自分のためになるから & 229 & -201 & 5 & 019 & -02 & 09 & -21 & 484 \\
\hline 12 自分は選手だから & 069 & 070 & 5 & 031 & -02 & 296 & 31 & 487 \\
\hline 42 意欲的に指道してもらえるから & 314 & -058 & 553 & 52 & 10 & 087 & -00 & 706 \\
\hline 37 一緒に絊習 & 265 & -00 & 136 & 701 & 137 & 120 & -0 & 617 \\
\hline 38 まじめな人だから & 352 & -031 & 12 & 687 & 14 & 071 & -01 & 40 \\
\hline 40 熱意を持って接してくれ & 341 & -184 & 49 & 1 & -0 & 140 & -1 & 724 \\
\hline 36 部員のことを本当に考え & 290 & -125 & 43 & 10 & 009 & 210 & -162 & 623 \\
\hline 16 監督の指示だから & 1 & 22 & 2 & 125 & 72 & 055 & 04 & 663 \\
\hline 27 監督に従うのはあたりまえだか & 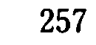 & 15 & & & 6 & 124 & -24 & 756 \\
\hline 41 監督は指算者たから & 16 & 20 & 325 & & 673 & -090 & 164 & 721 \\
\hline 9 監督の言うことは守らねばならないから & 19 & 19 & 36 & 1 & 6. & 116 & -31 & 710 \\
\hline 4 監督の言うことを闗くのは当然 & 20 & 03 & 40 & 0 & 5 & 164 & -38 & 700 \\
\hline 32目上の人たから & 187 & 326 & 111 & 325 & 508 & 035 & 134 & 536 \\
\hline 2 監督が好きだから & 406 & -02 & 031 & 6 & 08 & 640 & -169 & 652 \\
\hline 34 自分が信頼 & 17 & 00 & 31 & & 0 & & & 494 \\
\hline 19 監督がおもしろい人だから & 3 & 13 & -00 & 347 & 1( & 5 & 00 & 558 \\
\hline の事をよく知っていると & 396 & 056 & 428 & 206 & -050 & 501 & -058 & 644 \\
\hline 14 監督がやさしい人たかから & 360 & 02 & -087 & & 3. & & & 58 \\
\hline 15 むりやり従わせるから & -094 & 448 & -140 & -3 & 0 & 0 & 49 & 609 \\
\hline 24 監督の言らことが正しいと思らから & 463 & -118 & 492 & 259 & 197 & 118 & -241 & 648 \\
\hline 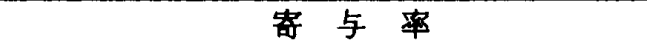 & $19 !$ & 096 & 09 & 07 & 06 & 0 & 041 & 634 \\
\hline 累素寄与率 & 195 & 291 & 390 & 467 & 536 & 593 & 634 & (634) \\
\hline 回枟前 の固有 & 14.12 & 4.78 & 2.38 & 1.59 & 1.41 & 1.22 & 1.12 & 26.62 \\
\hline
\end{tabular}

回転前の固有值を除いて，小数点省略.

.500以上の因子負荷を太ゴシック表記. 
琱查対象：高校運動部に所属する高校 1，2 年生389名（男子126名，女子263名）。

倜查方法：各運動部の願問教員に調查に関し て承諾を得た後，各運動部あてに，以下に述べ る 2 種類の調査からなる冊子を郵送した。この 冊子は，䫏問数員によって配付および回收され た後，各運動部ごとに一括して返送された。尚， 調査においては，対象が高校運動部員であるこ とを考虑して，監督やューチなどの敩密な区別 を行なわずに，実際に指導にあたっている指導 者について回答するよらに求め, このような人 を便宜上，「監督」と統一して表記した。

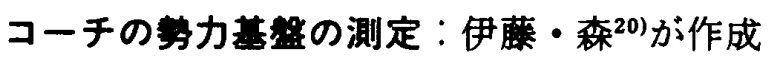
した質問紙（60項目）の内容を再検討し，新た に42項目の質問紙として再構成した（表 1)。回 答方法は，各質問文が「現在の監督の指示に従 う理由」としてあてはまる程度を「全くあては まらない」(1点) から「ょくあてはまる」（6 点）までの 6 段階で評定するとい5すのであっ た。

伊藤・森 ${ }^{20)}$ は，因子分析による因子として，4 つの愬力基盤を抽出したが，このらち，指導性 の因子は概念的に異なるいくつかの下位因子を 含んでいると考えられる。 また，技術指導の因 子は, コーチの技術指導能力の認知を暗黙には 想定しているものの，この因子に負荷の高い項 目のほとんどは，選手の動機づけを測定してい ると考えられ，この他にもコーチの智力を測定 するには，ふさわしくないと考えられる項目も いくつか含まれていた。このため, 本研究では, 伊藤・森 ${ }^{20)}$ の質問紙より36項目を用語を検討し た上で採用した。さらに，教師の势力に関する 研究 14),15),35)を参考に，6 項目を新たに加え，合 計42項目の質問紙を構成した。

コーチからの影需に閶する測定：以下の $5 つ$ の尺度について，各質問文か「頃感じている ことにあてはまる程度」を，「全くあてはまらな い」（1点）から「よくあてはまる」（6点）ま での 6 段階で評定させた。

(1) 被影敚感: コーチからの影敏に関する評 定.「私の技術や戦術がいまあるのは，監督の指
導のおかげである」など 3 項目。

(2) 满足度：コーチに対する総体的な評価. 「私は監督の指導を信頼している」など 4 項目。 (3) 所属運動部への関心.「毎日, 練習に行く のがなんとなく楽しい」など 3 項目。

(4) 練習への意欲.「もっと練習して上手にな りたいと努力している」など 3 項目。

(5) チームメイトとの関係.「私が困っている ときには，クラプの仲間が助けてくれる」など 3 項目.

\section{結果}

\section{コーチの类力の基盤}

コーチの勢力の基盤を明らかにするため, コーチの勢力基盤質問紙への回答を主成分分析 し, 固有值 1.00 以上の 7 因子に関して, ノーマ ル・バリマックス回転を施したところ，第 6 因 子までが解釈可能であった（表 1 ）.

第 1 因子は，「技術的に尊敬しているから」「監 督がこの競技のことをよく知っているから」「監 督はよい括手本だから」監督のようになりたい から」など，選手がコーチは専門的な知識や高 度な技能を持っていると認識することと、コー チに対して同一化の意図を持つことであり，こ の因子を専門・参照性と解釈した。第 2 因子は， 「監督に叱られるから」「監督がこわいから」な と，指示に従わない場合にコーチから罚を受け ることの予想やコーチへの畏怖であり，この因 子を罚の奇威と解釈した。第 3 因子は，「指示に 従ら方からまくいくから」自分のためになるか ら」なと，指示に従らことが自身の利益につな がることへの期待であり，この因子を利益への 期待と解釈した．第 4 因子は，「熱意をむって接 してくれるから」部貣のことを本当に考えてく れるから」など、コーチの熱意や，指導におけ る積極的な態度の認知であり，この因子を指導 意欲と解积した。第 5 因子は，「監督の指示たか ら」「監督に従らのはあたりまえたから」など， コーチにしたがうのは当然であるといら内在化 された規範であり，この因子を正当性と解釈し た。第 6 因子は，「監督が好きだから」「自分が 
信頼されているから」など、コーチとの心理的 な近さと，自分を受け入れてるらえるといら印 象であり，この因子を親近・受容性と解积した。 コーチの慜力は, 以上の慜力基盤に基ついて, 専門・参照势力, 罚势力, 利益䡃力, 指揱意欲 愬力, 正当勢力, 親近・受容繁力の 6 タイプの 愬力から構成されていると考えられる.そこで， 各因子の5ちのいずれか一つのみに.500以上の 負荷を示した項目の得点を各因子毎に合計し， これをそれぞれの基盤に基ついた勢力の得点と した。

次に, 各勢力間の関係を明らかにするために, 各繁力得点間の相関行列（表 2) をむとに，固 有值1.00を基準に主成分分析およびノーマル・ バリマックス回転を施したところ，2つの因子
が得られた. 各勢力得点の 2 つの因子への因子 負荷圼をプロットしたものが図 1 である.

因 1 より，専門・参照，利益，指学意欲お上 び親近・受容力は，第 1 因子への負荷が高く， 第 2 因子への負荷は低い。これらは、コーチの 属性あるいはコーチと選手との個人的な関係を

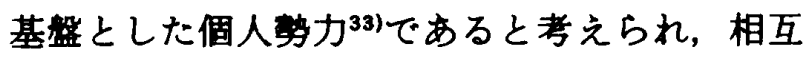
に関連しあっていると考えられる。これに対し て，埆等力は，第 1 因子への負荷は低く，第 2 因子への負荷が高いことから，先の 4 愬力とは 異なった特質を持つ慜力であることがうかがえ る. 正当勢力に成しては，他のすべての慜力と 有意な正の相网を示し，どちらの特質をる持つ ことが予想される。また，埆および正当等力は， コーチと選手といら社会的な位固阅係を背景と

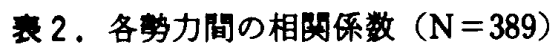

\begin{tabular}{|c|c|c|c|c|c|}
\hline & 專門・参照 & 㔊 & 利 益 & 指噵意欲 & 正 当 \\
\hline 箱 & 020 & & & & \\
\hline 利 益 & $528^{* * * *}$ & -090 & & & \\
\hline 指道意欲 & $645^{* * *}$ & $-187^{* * *}$ & $541^{* * *}$ & & \\
\hline 正 当 & $495^{* * *}$ & $253^{* * *}$ & $450^{* * *}$ & $462^{* * *}$ & \\
\hline 親近・受容 & $664^{* * *}$ & -012 & $470^{* * *}$ & $597^{* * *}$ & $411^{* * * *}$ \\
\hline
\end{tabular}

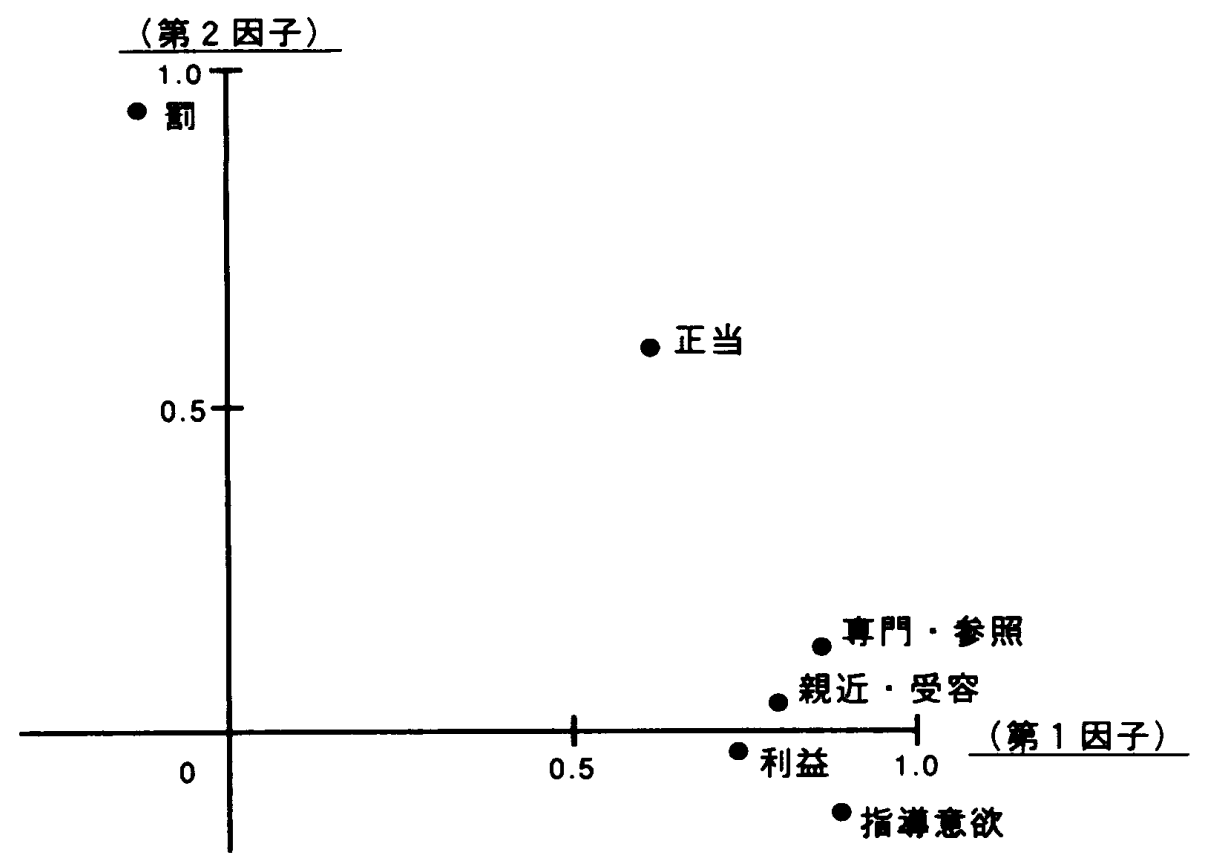

图 1. 各等力得点の第 1 および第 2 因子への負荷至（N=389） 


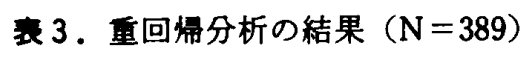

上段：相蔺保数

下段：偏相成倸数

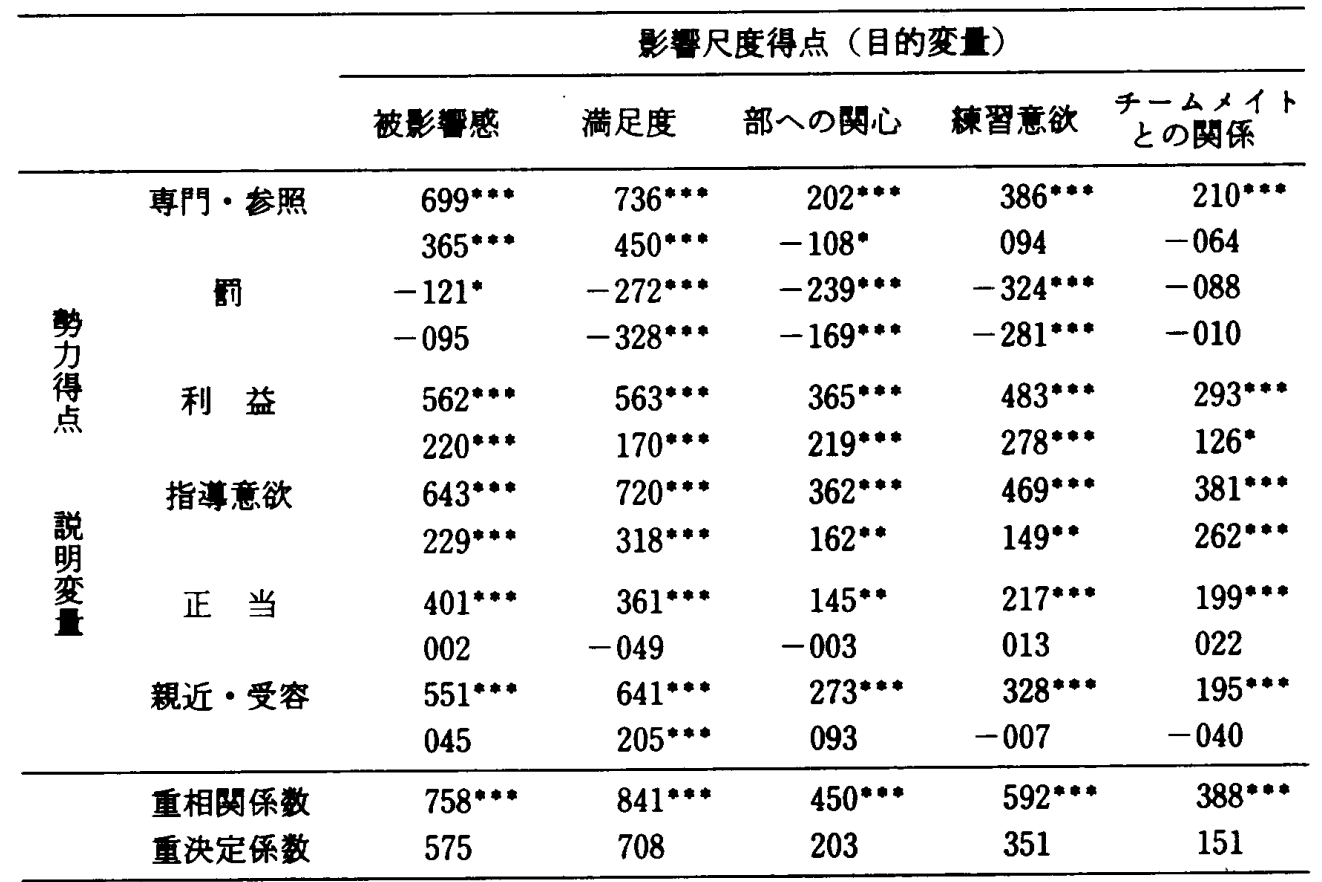

小数点省略。

重相関係数および重決定係数は自由度調整済みの値である。

$" \mathrm{p}<.05, * \mathrm{p}<.01, \cdots * \mathrm{p}<.001$.

した位置愬力33)であると考えられる。

\section{コーチの务力の機能}

まず, コーチからの影敏に閶する質問紙の信 頼性を検討するために，被影漂感，满足感，所 属運動部への成心，練習意欲，およびチームメ イトとの成係の 5 つの尺度の内的整合性係数 ${ }^{23)}$ を算出した。係数は $0.8686 か ら 0.9513$ と十分に 高いるのであり，各尺度は内的に一貫したもの であると考えられるため，各尺度内の項目得点 を合計し，それぞれの影管尺度得点とした。

次に，各影謷尺度へのコーチの繁力の奻果を 検討するために，6つの势力を説明変量とし， 各影䈏尺度のそれぞれを目的变量とした，一括 多量型投入法による重回䱁分析を行なった（表 3 ).

各影制尺度に対する重相阙係数は, 全て0.1\% 水準で有意であり，特に被影響感と満足度にお ける重相関および重決定係数は高いるのであっ た. 各繁力の偏相関係数は, 専門・参照, 利益,
指咅意欲，および親近・受容势力において正で 有意な值であった。特に满足度に対してはこれ らの 4 慜力得点の偏相閣係数がすへて0.1\%水 準で有意であり，被影答に対しては，専門・ 参照, 利益、および指導意欲繁力が有意であっ た。また，選手の䔔応に闺する部への関心，練 習意欲，チームメイトとの関係の 2 つの尺度に 対しては，周勢力以外の 5 等力すべてが有意で 正の相威係数を示したすのの，偏相関保数は利 益および指咅意欲繁力のみで有意であった。一 方，图势力はすべての影很尺度との間に負の相 関係数および偏相関係数を示した。この中には， 有意水準に達しているものも達していないるの ああったが，すべてが負の值であったことは重 要である。これに対して，正当勢力は，すべて の影很尺度との間に有意な正の相威係数を示し ながら，偏相成係数はすへて有意水準に達しな かった. 


\section{考 \\ コーチの冬力の基盘}

家

本研究では，まず，指導に拈けるコーチの専 門性と参照性，罚の䇆威，コーチの指導が自身 の利益につながることへの期待, コーチの指導 意欲、コーチから指導を受けることの正当性, およびューチとの親近性やューチの受容性が コーチの慜力の基盤となっていることが見い出 された。

コーチの勢力基盤のうち，専門性，参照性， 罚の卑威，正当性は，French and Raven ${ }^{12)}$ 方提 唱した専門勢力，参照勢力，強制就力，および 正当勢力のそれぞれの基盤と対応するものであ る。またこれらは，教育場面においても，同 様に勢力の基盤とされている14),15),35),37). 従っ て，これらの繁力基盤は，一般的な場面および 教育場面と同様に，スポーツ指莩場面に括いて も、コーチの潜在的な影䈏力の基礎となるるの であると言える。ただし、コーチの専門性と参 照性が因子として1つにまとまったことは, コーチの持つ専門的な知識や技能は，選手が身 につけるべきすのであり，専門的な知識や高度 な技能を持ったューチは，選手にとってはモデ ルとなり，同一化の対象となるといらスボーッ 指尊の場面の特質を反映しているすのと考えら れる。

また，教師の勢力に成する研究は，上に挙げ た 4 つの繁力基盤以外に，親近性，受容性，外 見性，明朗性などを，教師に特有な慜力の基盤 として見出している。本研究の結果は，これら のうち外見性と明朗性を見出すことができな かったものの，親近性と受容性を因子として抽 出しており，これらについては，教育やスボー ツ指導などの指学一被指咅を軸にした場面で見 られる勢力基盤ではないかと考えられる。

この親近・受容性とは逆に, 利益への期待は, 教育場面での繁力研究では見出されていない。 しかし「うまくなる」あるいは「直してもらえ る」など，指導に従らことが「自分のためにな る」といら利益への期待は，Oが P に対して報
酬をもたらすことができると P が認知すると いら，French and Ravenの報酬势力の基盤と 類似した側面を持つものである。ただしFrench and Ravenの報酬勢力においては，報酬とは単 に, O に従うことで与えられる報酬であり，Pの 内発的動機つけを低下させる可能性を持った， 統制的な外的報酬7),8)であると考えられる。この よらな，報酬の道具性ゆえに，Student ${ }^{333}$ は，強 制勢力および正当勢力とともに，報酬勢力を位 置勢力のカテェ゙リーに包括している。しかし， このよらな報酬が教育場面で用いられることは 少ないと思われ，このために，報酬勢力が教師 の勢力として見出されていないのではないかと 考えられる。

これに対して，本研究に打ける利益とは，ス ボーツ活動における対処能力の向上や課題の達 成といら内的な報酬，あるいは，内発的動機つ けを強化するよらな報酬であると考えられる。 このよらな意味での報酬は，Oの位置によって もたらされるものではないため，コーチの利益 勢力は，個人勢力のカテゴリーに含まれるべき であると考える、このことは，利益屰力が，他 の個人慜力との間に高い相関を示したことから もらかがえる。また，達成閶連場面において， 課題達成への期待が，その人の達成への動機つ けや達成行動に影管を及ぼすことは多くの研究

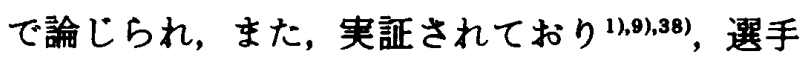
の動機づけを高めるために重要な慜力であると 考えられる。

指咅意欲に威しては，これと類似した勢力基 盤は，従来の研究においてははとんど見られな い。しかし，体育教師の勢力を検討した平川15) は, 本研究と同様に高校生を対象とした場合に, 体育教師の人間性と热練性の下位因子として熱 意性を抽出している，体育指尊とスポーツ指導 は, 内容, 方法の点からかなりの共通性があり, 指導意欲はスボーツ指導を行ならューチの勢力 の基盤としても妥当なるのであると考えられ る.

また，原因㷌属理諭を対人関係場面に抎張し たWeiner ${ }^{38}$ は，他者の行動の原因を推論する 
際に, 統御可能性次元がその他者への感情反応 を規定し，その他者への行動に変化があたらさ れることを示唆し，統御可能な内的要因として 努力を挙げている。本研究においでも，コーチ の指姜意欲に関する認知が，負の感情を喚起す ることによって機能する图の認知と有意な負の 相関を示したことを考虑すれば，選手がューチ の指導意欲を認知するはど、コーチに対する選 手の正の感情が増大すると考えられよら。

さらに，教師の熱心さの重要性を多くの研究 が論じている2,28),29)ことを考えあわせれば， ス ポーツ指導におけるコーチの熱意や積極的な態 度を選手が認知することは、コーチの繁力の基 盤として重要であると考えられる。

\section{コーチの类力の機能}

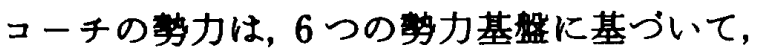
専門・参照势力, 略等力, 利益勢力, 指導意欲 势力, 正当势力, 親近・受容煭力に分類された。

重回㷌分析の結果においては，コーチの個人 勢力と考えられる専門・参照, 利益, 指導意欲, および親近・受容势力が，影稫尺度との間に有 意な正の偏相威を示した。この結果は、コーチ がその地位ではなく，自身の望ましい属性や選 手との積極的で䁔かい関係に基ついて指導にあ たっていると選手が認知することで, 選手に対 するコーチからの影留やコーチに対する满足が あたらされることが多くなり，さらに，選手の スポーツ活動への高底に対しても良い奻果が生 み出されることを示している。

この中でも，利益勢力と指意欲勢力は，す べての影篅尺度との間に有意な正の相関および 偏相関を示している。このことは，コーチの指 導に従うことが自身の利益につながるという認 知に基つく利益敏力と，コーチの指尊における 熱意に基つく指蒠意欲势力が，コーチの個人势 力の中でる，中心的な機能を果すことを意味し ている.

加光て，これらの勢力の基盤は，従来の研 究12),13),14),15),34),35)では，はとんど見られないにも かかわらず, 本研究においては，因子分析によっ て因子として抽出された。このことからも，こ
れらの勢力が, スポーツ指導場面において、コー チに特に必要とされると考えられる。言い換え るならば,コーチの指導が有意義なものであり， コーチが熱心に指導にあたっていると選手に認 知されることで，指導が効果的なるのになると 予想される。

また，行動の結果に対する期待が行動や動機 づけに変化をもたらすことは，様々な場面で示 されており 1),91,38), 利益勢力は, 「自分のためにな る」ことに対して選手に正の期待をるたらすこ とで，選手の動機づけを高めると予想される。

一方，指尊意欲勢力は，コーチに対する選手の 感情と関連し，選手のスポーッ活動への適応に 対しても効果を示したことから，コーチに対す る感情が活動の場全体へと汎化されることが予 想される. 従って, 利益慜力と指咅意欲势力は, スポーツ活動における選手の期待と感情が, 認 知と行動を媒介するといら観点 ${ }^{19)}$ からも重要で あると考えられる。

再門・参照勢力は，被影䇾感および満足度に 対しては有意で高い正の偏相関を示し，この結 果は，多くの一般的な状況での勢力の機能に闺 する研究と一致する27),31),331,39). しかし，この等 力は, 所属運動部への関心に対しては，有意な 負の偏相関を示した。コーチの専門的な知識は, コーチが選手に利益をるたらすための必要条件 であると考えられよう。このため，コーチが専 門的で高度な知識や技能を持っていると認知さ れることによって、コーチが選手に影第を与え る可能性は高くなり，選手のコーチに対する評 価むボジティブなるのとなるであろ5.しかし， その知識や技能が選手に利益をるたらすような 形で、コーチの櫴極的な態度とともに提供され るのでなければ，選手の適応を阻害する可能性 をす秘めていると考えられる。これは招そらく， 高度な専門的知識や技能を持ったコーチは，指 導にあたっている選手に対しても，より高度な あのを要求することで，選手に過度の緊張を与 えるためではないかと思われる。このことに関 しては,リーダーシップ行動の PM 理論26)にお いて,リーダーの目標達成機能における圧力因 
子が，集団のメンバーに過度の婜張を与えると されていることと共通する．従って，コーチの 勢力の機能の観点からも，単に競技に対する専 門的な知識や技能を持つだけでなく，指尔にあ たっている選手にふさわしい目標設定, 練習内 容・方法，スケシュールなどを提供できる資質 がコーチには要求されると言えよ5.

親近・受容勢力は，満足度以外の影管尺度に 対しては有意な偏相䦛を示さなかった。従って， この繁力は，コーチの評価をポシティプなるの とするが、 コーチの影算の試みを促進するよう な, 主要なるのではないと考えられる.しかし， この慜力の基盤は，教師の勢力に成する研究で は必ず見出されており，スポーツ指導の場面で も，なんらかの機能を果していることが予想さ れる.たとえば, リーダーシップ行動の PM 理

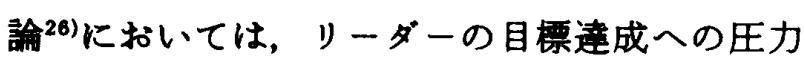
から生じる桑張を、リーダーのメンバーへの配 虙が解消するために, PM 型のリーダーシップ 行動が有奻であることが示されている.このこ とを考慮すれば，親近・受容愂力は必ずしも主 要な等力ではないるのの, 利益等力, 指導意欲 愬力，専門・参照勢力を補らのではないかと考 えられる.

词策力については，効果が小さいことは多く の研究で示されており，本研究においてもすへ ての影管尺度に対して負の相開および偏相関を 示した。この結果は，数師の知力について検討

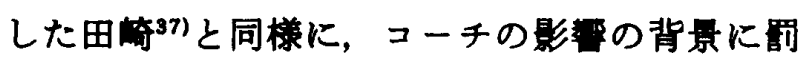
が認知される場合には、コーチから選手への影 留力は弱くなり，選手の適応の度合いる低くな ることを意味する。しかし，このことは，指導 において，㓮を全く用いないことを支持するも のではない，指尊一被指尊を軸とした場面にお いて，望ましくない行動に対して娚による負の 強化を与えることは必要なことであると考えら れる。

また，罚の奻果に成しては、コーチからの影 雾がどの程度内面化されるかを考虑する必要が あると思われる。Festinger ${ }^{10)}$ および Kelman ${ }^{211}$ は，社会的影管を影管が P に内面化される程度
によって，表面的な追従とより内面化された影 湾とを区別し，さらに，影䇾の内面化の程度は， 影䇾の背景となっているものによって異なると 述べている，両研究をまとめれば，追従は報酬 や罚などを手段とした統制によって起こり，影

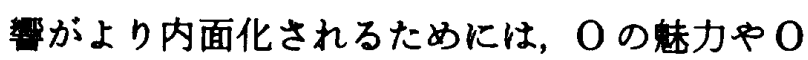

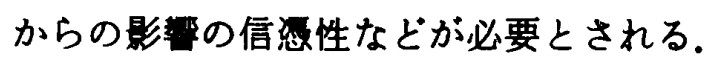

この指摘を考虑するならば，本研究における 被影留感の尺度は，質問紙への回答によって得 られており，単なる追従の段階ではなく，私的 に受容されている影管を測定するすのであると 考えられる、従って、コーチの罚勢力がこの尺 度に対して、はとんど無相関であったことは， 両者の結果と一致するものであると考兄られ る、もし，コーチが，自身の監視のもとで，望 ましくない行動をさせないよ5にすることのみ を意図するのであれば，固愬力に依扰した影留 を用いることで十分であり，罚の即効性と简便 さ32)はコーチにとって有用なるのであると言え よ5.

しかし，周の奻果は，周が不快な感情を喚起 することに依拠しており，実際，㓮势力は，满 足度と逼応の尺度に対して負の偏相阔を示して いる．若年居を対象としたスポーツ指辛におい ては特に，選手がスポーツ活動を楽しみ，自発 的，積極的にスポーッ活䖝に取り組むように， さらに，スポーッ活動に価値を見出すように導 くことも，コーチの果すべき重要な役割であろ 5。このよらな観点からも，指導の中で，固は あくまです補助的に，取小限用いられるべきす のであり、コーチが涸を用いる祭には，細心の 注意が必要であることが，コ一チの慜力に咸す る本研究からす指揙されよう。

取後に，正当勢力については，従来，文化的 価值, 社会的粠造の受容, 既に正当であると認 められたものからの任命，正当な手続きなどを 基礎にしているとされており ${ }^{12)}$ ，Oの社会的な 位置に根ざした茄力であるとされてきた れに対して，今井 ${ }^{16)}$ は，正当愬力は専門势力と参 照慜力を基礎とした個人吿力であると主張して いる. 本研究において, 正当勢力はューチの個 
人势力と考えられる利益，指導意欲，専門・参 照, 親近・受容の各势力との間にも，位置勢力 のカテゴリーに含まれる罷勢力との間にも, 有 意な正の相威を示した。従って, コーチの正当 勢力は変化・社会的な背景よりる個人勢力を背 景として成立していながらも，位置勢力として の側面を持っているのではないかと考えられ る.

また，教師の勢力に関する研究14),36),37)では， 正当势力がもっとも大きな機能を果していた が, 本研究ではこのよ5な結果は示されず, 正 当愬力の影慜尺度への偏相関はすべて有意では なかった．このことは，コーチの正当愬力が, 必ずしも重要なものではなく, 単独では機能し ないすのであることを意味する，従って，指導 一被指導を軸とした類似した過程でありながら む, 教師と生徒といら公的な闺係における過程 と、コーチと選手といら総体的に私的な関係に おける過程においては, 正当势力の機能は異 なったものとなると考えられる。このことから， 学校の運動部の顧問である教師が，選手として の生徒を指莩する際には，特に，教師と生徒の 社会的な位置威係に依拠することのないよら に，選手である生徒との相互作用の方法に留意 する必要があることが示唆されよう。

\section{まと め}

本研究は、スボーツ指導を社会的影变過程の 観点から捉えた上で、 こーチの等力の基盤とそ の機能を明らかにすることを目的として行なわ れた。対象は高校運動部員であった。

コーチの勢力について：コーチの勢力の基盤 に関する調査から，専門・参照性，罚の离威， 利益への期待, 指導意欲, 正当性, および親近・ 受容性の 6 つの等力基盤が見出された。各基盤 に基ついて，コーチの勢力は 6 タイプに分類さ れ，それぞれ尃門・参照繁力，罚慜力，利益勢 力, 指導意欲勢力, 正当勢力, および親近・受 容勢力と解釈された。

コーチの势力の機能について：コーチの势力 はさらに, 個人劽力と位固勢力に分類され, 選
手に対するコーチの影響は個人勢力に大きく規 定された。なかでも，利益慜力と指導意欲勢力 が，選手のコーチからの被影敕感やコーチへの 満足度のみならず, 活動における適応感を大き く規定する重要な要因であると考えられた。専 門・参照勢力は、コーチからの被影響感を強め, コーチの評価をボジティブなるのとするが，行 使のしかたによっては，選手の適応を阻害する 可能性も秘めていると考えられた．親近・受容 勢力は，単独ではコーチの評価をボシテティブな ものとするのみであるが，他の勢力を補らこと が予想された。罣勢力の行使による影策は，選 手に内面化されることが少なく，選手の適応に 対して負の効果をるつと考えられる．正当勢力 は，他の勢力の影䉕を除去した場合には，5つ の影䇾尺度得点に対して奻果を持たず、コーチ の個人愬力を基礎に成立していながら，罚勢力 と同様の機能を果している勢力であると考えら れる。

\section{引用・基文献}

1) Atkinson, J.W. and Feather, N.T. (Eds.), A theory of achivement motivation, Wiley: New York, 1966. Pp. 392.

2) Brophy, J.E. and Good, T.L., Teacher-student relationships: Cause and consequences, Holt, Rinehart, and Winston: New York, 1974. pp. 251 -54 .

3) Cartwright, D., "Power: A negrected variable in social psychology," in Cartwright, D. (Ed.), Studies in social power, University of Michigan Press : Ann Arbor, Michigan, 1959. pp. 1-14.

4) Cartwright, D., "A field theory conception of power," in Cartwright, D. (Ed.), Studies in social power, University of Michigan Press: Ann Arbor, Michigan, 1959. pp. 183-220.

5) Cartwright, D., "Influence, leadership, control," in March, J.G. (Ed.), Handbook of organizations, Rand McNally College Publishing: Chicago, 1965. pp. 1-47.

6) Dahl, R.A., "The concept of power," Behavioral Science, $2: 201-15,1957$.

7）デシ(安藤延男・石田梅男 訳), 内発的動機づけ，諴 信害房, 1980. Pp. 374. (Deci, E.L., Intrinsicmotivation, Plenum Press: New York, 1975.)

8）デシ(石田梅男 訳), 自己決定の心理学, 誠信書房, 1985. Pp. 316. (Deci, E.L., The psychology of self determination, Lexington Books: New York, 
1980.)

9) Feahther, N.T., Expectancy and action: Expectancy-value models in psychology, Lawrence Erlbaum Associates: Hillsdale, New Jersey, 1982. Pp. 436.

10) Festinger, L., "An analysis of compliant behavior," in Sherif, M. and Wilson, M.O. (Eds.), Group relations at the crossroads, Harper: New York, 1953. pp. $232-56$.

11) French, J.R.P. Jr., "A formal theory of social power," Psychological Review, 63 : 181-94, 1956.

12) French, J.R.P. Jr. and Raven, B., "The basis of social power," in Cartwright, D. (Ed.), Studies in social power, University of Michigan Press : Ann Arbor, Michigan, 1959. pp. 150-67.

13) Gold, M., "Power in the classroom," Sociometry, $21: 51-60,1958$.

14）浜名外吾男・天根哲治・木山博文「教師の势力源 とその影に网する数師と児章の認知」教育心理学 研究, $31: 220-28,1983$.

15）平川澄子「体育教師の等力资源に间する研究一学習 者の発迬段階別にみた比整を中心に一」お莱の水女 子大学人文科学紀要, $41: 129-42,1987$.

16）今井考昭「社会的繁力：その基盤の相互网係と今後 の研究課題」社会心理学評論, $1: 49-56,1981$.

17）今井考昭「親子间俰における社会的势力の基盤」社 会心理学研究, $1: 35-41,1986$.

18）今井考昭「影整者が保持する社会的第力の認知と被

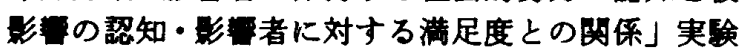
社会心理学研究, $26: 163-73,1987$

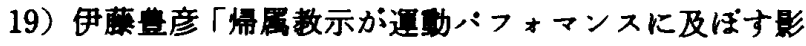
需について」体育学研究, $28: 299-308,1984$.


手の認知一高校バレーボール部員についてー」岛根 大学教育学部紀要 (教育科学)，21:25-30, 1987.

21) Kelman, H.C., "Compliance, identification, and internalization three process of attitude change," Journal of Conflict Resolution, 2: 51-60, 1958.

22) Kiesler, C.A. and Kiesler, S.B., Conformity, Addison-Wesley : Reading, Massachusetts, 1969. p. 69.

23) Kuder, G.F. and Richardson, M.W., "The theory of the estimation of test reliability," Psychometrika, 2 : 151-60, 1937.

24) Lewin, K., "Appendix. Analysis of the concepts whole, differentiation, and Unity," in Cartwright, D. (Ed.), Field theory in social science : Selected theoretical papers, Tavistok: London, 1952. pp. 335-38.
25) Lewin, K., Lippit, R. and White, R.K., "Patterns of aggressive behavior in experimentally created 'social climates'," Journal of Social Psychology, $10: 271-99,1939$.

26）三隅二不二,リーダーシップ行動の科学, 有斐图, 1978. Pp. 500.

27) Podsakoff, P.M. and Schreisheim, C.A., "Field studies of French and Raven's bases of power: Critique, reanalysis, and suggestion for future research," Psychological Bulletin, 97 : 387-411, 1985.

28) Rosenshine, B., "Enthusiastic teaching: A research review," School Review, 78: 499-514, 1970.

29) Rosenshine, B. and Furst, N., "Research on teacher performance criteria," in Smith, B. (Ed.), Research in teacher education: A symposium, Prentice-Hall: Englewood Cliffs, New Jersey, 1971. pp. 37-72.

30) Shaw, M.E., Group dynamics : The psychology of small group behavior, 3rd ed., McGraw-Hill : New York, 1981. pp. 213-304.

31) Shetty, Y.K., "Managerial power and organization effectiveness: A contingency analysis," Journal of Management Studies, 15: 176-86, 1978.

32) Stogdill, R.M., Handbook of leadership: A survey of theory and research, Free Press: New York, 1974, p. 293.

33) Student, K.R., "Supervisory influence and workgroup performance," Journal of Applied Psychology, $52: 188-94,1968$.

34）田崎敏昭「学級集団における等力の源泉」佐賀大学 教育学部研究論文集, $24: 105-18,1976$.

35）田崎敏昭「児童・生徒に上る教師の力源泉の認知」 実臥社会心理学研究, $18: 129-38,1979$.

36）田崎敏昭「教師のリーダーシッブ行動類型と妿力の 源泉」実検社会心理学研究, $20: 137-45,1981$.

37）田崎敏昭「教師の智力资源とモラール」佐加大学教 育学部研究諭文集, $31: 147-63,1984$.

38) Weiner, B., "An attributional theory of achievement motivation and emotion," Psychological Review, $92: 548-73,1985$.

39) Zander, A. and Curtis, T., "Effects of social power on aspiration setting and striving," Jour. nal of Abnormal and Social Psychology, $64: 63$ $-74,1962$. 